\title{
Thormation
}

Nordic Journal of Art and Research

ISSN: 1893-2479

$\underline{\text { www.artandresearch.info }}$

\section{Den kulturelle skolesekken: Passiv tilstedeværelse eller aktiv danning?}

\author{
Kristin Helene Oftedal ${ }^{1}$ \\ Dukkespiller, skuespiller
}

Sammendrag: Med utgangspunkt i erfaringer med Den kulturelle skolesekken - en nasjonal satsing som skal bidra til at alle skoleelever i Norge får møte profesjonell kunst og kultur av alle slag - ser denne artikkelen nærmere på kunst som estetisk erfaring. På bakgrunn av filosofene Jacques Rancières og John Deweys tekster, undersøkes danningspotensialet i estetisk erfaring som resepsjon, eller mottagelse. Fra henholdsvis et politisk og et evolusjonistisk perspektiv, peker både Rancière og Dewey på at den estetiske erfaring handler om en indre aktivitet som både er skapende og kritisk. Kunsterfaringen kjennetegnes ikke bare av harmoniske stunder av samsvar, men er også er en prosess som betinges av spenningsfull rekonstruksjon og tolkning av det følte og sansede. Slik tilbyr publikumsrollen mulighet for aktiv danning.

Emneord: Kunst, estetisk erfaring, danning, Den kulturelle skolesekken, John Dewey, Jacques Rancière.

Den kulturelle skolesekken (DKS) er et samarbeidsprosjekt mellom kultur- og opplæringssektoren som skal sikre at alle elever i norsk skole får møte profesjonelle kunst- og kulturtilbud med høy kunstnerisk kvalitet. DKS har vært en del av regjeringens kulturpolitiske satsing for grunnskolen siden 2001, og har etter hvert blitt utvidet også til videregående skole. Dette betyr at alle elever - fra 6 til 19 år - nå er innlemmet i ordningen.

Prosjektet har vært gjenstand for omfattende evalueringer. Da NIFU STEP (Nordisk institutt for studier av innovasjon, forskning og utdanning) våren 2009 gjennomførte spørringer til skole-Norge om erfaringene med DKS (Vibe, Evensen \& Hovdhagen, 2009), kom det fram en uttalt bekymring for den publikumsrollen elevene blir tilbudt. Publikumsrollen hevdes å gjøre eleven til en passiv tilskuer.

I en tidligere evaluering (Borgen \& Brandt, 2006) skilles det mellom dialogisk og monologisk kommunikasjon i kunst- og kulturformidlingen, der tradisjonelle formidlingsformer som forestilling, utstilling, konsert, etc. karakteriseres som monologiske. Dette til forskjell fra dialogiske former som

\footnotetext{
${ }^{1}$ Rådyrveien 2, 1450 Nesoddtangen, Norway. E-mail: hele-oft@online.no
} 
beskrives som aktive og deltagende prosesser sammen med kunstnere og kulturarbeidere. Men er mangel på verbal eller fysisk kommunikasjon med utøvere nødvendigvis bekymringsfullt? Og bør en slik publikumsrolle nødvendigvis forstås som passiv?

Jeg har mangeårig erfaring som utøver i teater, og har møtt barne- og ungdomspublikum i skolenes gymsaler og fra store kulturhusscener. Ofte har premisset for oppsetningene vært "den fjerde veggen" mellom scene og sal. Selv om det da ikke legges opp til direkte interaksjon mellom publikum og utøvere på scenen, behøver ikke det bety manglende kommunikasjon. Barns respons i form av latter eller gode råd til det som skjer på scenen, er med på å skape en kontakt som preger den enkelte forestilling. Samtidig kan barn være et ærlig publikum, og en stødig, og til dels høylytt, indikator på en teateroppsetnings eventuelle svake partier. Men min erfaring er også at publikum, gjennom sitt blotte nærvær, setter sitt preg på den enkelte forestilling. Også publikums tilstedeværelse som "stille persepsjon" kan man fornemme fra scenen. Man merker om publikum lar seg rive med, selv når de sitter ganske tause og i ro.

Her vil jeg se nærmere på publikumsrollen, hvilket vil si estetisk erfaring som mottagelse, eller resepsjon. Fokus er kunstformidling for skoleelever - barn og ungdom. Ved å undersøke estetisk erfaring - hva slags type erfaring det er og hva denne type erfaring gir - vil jeg belyse danningspotensialet i kunst som formidling (se Steinsholt \& Dobson, 2011; Cannatella, 2008; Carrol, 2001).

Jeg vil undersøke estetisk erfaring som fenomen i lys av to ulike filosofiske perspektiv, henholdsvis franske Jacques Rancières (f. 1940) og amerikanske John Deweys (1859 -1952) tenkning. Jeg har valgt disse to fordi de har det til felles at de ser kunst som estetisk erfaring, og at de deler det syn at den estetiske erfaring som mottagelse og persepsjon rommer det vi kan betegne som "den estetiske dimensjon", en dimensjon innbefattende skaping, reseptiv opplevelse og kritisk refleksjon. Det estetiske sees ikke som noe iboende kunsten, men som en betraktningsmåte - og det vesentlige ved den estetiske erfaringen er ikke erfaringen som produkt, men som prosess. I motsetning til å se kunsten som autonom - et syn som vokste fram i Europa på 1800-tallet i pakt med en samfunnsmessig modernisering som førte til at kunstproduksjonen ikke lenger var underlagt førende oppdragsgivere ser Rancière og Dewey den enkeltes estetiske erfaring av kunst som singulær og autonom. Fokuset er den erfaring som skjer i det opplevende subjektet i møtet med objektet/verket. Rancières tenkning er spunnet ut av denne romantiske kunsttradisjonen der kunstens verdi og skjønnhet forstås som iboende kvaliteter ved kunstverket (se Elliot, 1995), men i likhet med pragmatikeren Dewey, ser ikke Rancière kunst og den estetiske erfaring som noe man kan isolere fra hverdagslivet, og slik representerer han et kritisk perspektiv. Dewey og Rancière ser begge kunsten i en sosial kontekst, og bærer på hver sin måte bud om kunstens danningspotensial.

Rancière og Dewey har, tross likheter, ulike innfallsvinkler for sin tenkning rundt kunst som erfaring, og de vektlegger forskjellige aspekter med hensyn til hva som er det essensielle og verdifulle ved den estetiske erfaringsformen. I denne artikkelen presenterer og diskuterer jeg Rancières og Deweys ulike perspektiver. Jeg starter med å si litt om danningsbegrepet. Deretter utforsker jeg hva Rancière og Dewey sier om den estetiske erfaringens danningspotensial. Til slutt noen refleksjoner rundt kunstmøter i Den kulturelle skolesekken (DKS).

DKS er forankret i den generelle del av læreplanen for grunnskolen, og skal bygge opp under de pedagogiske målsettingene i skolen (s. 10), målsettinger som også handler om elevenes "allmenne dannelse" (Kunnskapsdepartementet, 2006 s. 14). Stortingsmelding nr. 38 (2002 - 2003) understreker at "god kunst" rommer en rikdom som appellerer til både følelsesliv og kreative evner. "Dette er 
naudsynt for at den menneskelege danningsprosessen skal verte så heilskapleg som mogleg, slik at vi utviklar også mennesket sitt åndsliv, ikkje berre det kjølige intellekt og dei reint instrumentelle dugleikene" (St.meld. nr. 38 (2002 - 2003) s. 16, min utheving). Dannelse, eller danning, kan vanskelig måles. Ved ikke å handle om "nytte" i en pragmatisk og praktisk logikk, representerer både den estetiske erfaring og den danning som måtte komme i kjølevannet av denne erfaringsformen eller også rommes i erfaringen selv - en motvekt til den instrumentelle fornuft. Men hva innebærer det å dannes?

Danning er et historisk begrep, og derfor må forskjellige oppfatninger av danning forstås ut fra sin tid og sin sammenheng (Thavenius, 1995). Men mange danningsteoretikere, tross ulikheter $\mathrm{i}$ danningssyn, ser danning som et treleddet forhold. Forholdet omhandler mennesket $\mathrm{i}$ forhold til seg selv, der det fremheves at danning både er veien mot, og uttrykk for selvbestemmelse. Danning knyttes også til menneskets forhold til menneskeheten og verden, og menneskets forhold til et mer avgrenset samfunn. Danning er med andre ord ikke knyttet til ren subjektivisme, men settes inn i et mer kontekstuelt og praktisk perspektiv (Korsgaard \& Løvlie, 2003, s. 11). I synet på at danning også omhandler menneskets forhold til et sosialt fellesskap (polis), kan man hevde at politisk danning ligger implisitt i det filosofiske danningsbegrep. Med andre ord, en danning i og til polis.

Jacques Rancière integrerer - gjennom sine teorier om redistribusjon av det sanselige - det estetiske og det politiske. Det sanselige er både noe som er oppdelt og noe vi deler, det vil si; noe vi er sammen om. John Dewey, utforsker den estetiske erfaring fra et biologisk og evolusjonistisk perspektiv. Rancière og Dewey representerer ulike syn, men deres henholdsvis politiske og biologiske perspektiv på kunst som erfaring, kan gi et bilde av hva den estetiske erfaring kan sies å innbefatte, og slik bidra til vår tenkning omkring elevenes rolle som publikum i Den kulturelle skolesekken. Kan den best beskrives som passiv tilstedeværelse eller som aktiv danning?

Det kan virke paradoksalt å forsøke å sirkle inn den estetiske erfarings mulige danningspotensial, uten derved å innta et instrumentelt syn på kunst som erfaring. Men verken i Rancières eller Deweys tekster leser jeg dette som en motsetning. Vi skal se at den estetiske erfaringen ikke sees som formålsløs, selv om formålet også kan sies å ligge i erfaringen selv.

\section{Om estetisk erfaring}

Som dukkespiller og skuespiller vet jeg at jeg har vært med på å gi publikum opphevelser - og kanskje estetiske erfaringer. Å gjøre en erfaring betinges av oppmerksomhet, og er forankret både kroppslig, emosjonelt og intellektuelt, noe opplevelsen ikke nødvendigvis er. (Rancière, 2006a, 2009a, 2009b, 2009c; Dewey, 2008). Når en opplevelse nedfeller seg som en erfaring er opplevelsen ekstraordinær, og er erfaringen estetisk inneholder den både opplevelse, skaping og kritikk (Rancière, 2006a, 2009a, 2009b, 2009c; Dewey, 2008).

Den estetiske erfaring beskrives som en helhetlig opplevelse av nærvær, kjennetegnet av en fri og stadig omskiftelig relasjon mellom tankens skapende aktivitet og sanselig følsomhet (Rancière, 2006b, 2008b). Estetiske erfaringer adskiller seg fra ordinære erfaringer ved at det i den estetiske erfaring skjer en opphevelse av sanseerfaringenes alminnelige referansepunkter. I følge Rancière (2006b, 2008b) er det erfaringen av opphevelse, eller utsettelse av den timelige tid, som gir opplevelsen av en usedvanlig rom - tid dimensjon, og for Rancière representerer denne erfaringsformen en sansemessig avvisning av dualismen mellom sansning og tenkning.

Dewey (2008) peker også på opplevelsen av nærvær i den estetiske erfaring. Sansning, tenkning og følelser er, i tillegg til formål og mening, innkorporert i denne erfaringen, og den estetiske erfaring 
kjennetegnes ved at fortid, nåtid og framtid er til stede som en integrert del av øyeblikket. Den estetiske erfaringen oppleves som en helhetlig og avsluttet prosess, samtidig som den, i følge Dewey, med biologisk nødvendighet peker framover mot senere erfaringer av samme kvalitet. Den estetiske erfaring impliserer samkvem og interaksjon med omverdenen, og den vil virke forandrende, både på subjektet som erfarer og på dets omgivelser.

Er det mulig for oss (lærere og kunstnere) å se om eleven erfarer, for eksempel scenekunst, estetisk? Dette kan synes vanskelig, i og med at det i tilfelle er snakk om en indre vital aktivitet. Samtidig vil elever i ettertid kunne gi uttrykk for sin estetiske erfaring - eller eventuelt likegyldige opplevelse. I denne samtalen vil enhver som har bivånet en forestilling, kunne bidra med like stor tyngde. Dette fordi de allmennmenneskelige estetiske erfaringene alltid er individuelle, det vil si: de er autonome.

Rancière (2006a, 2006b) og Dewey (2008) deler det syn at den estetiske erfaring ikke utelukker noen objekter, hendelser eller fenomen, og at estetiske erfaringer ikke er forbeholdt kunst. Det er altså ikke kunsten som er uforbeholdent autonom, men den enkeltes erfaring av den. Men Rancière og Dewey anser begge, tross ulike utgangspunkt og agendaer, at kunst som erfaring nødvendigvis er estetisk, noe som ikke må forveksles med noe som er utvetydig vakkert eller pent. Det er opplevelsen av betydningsfullhet som kjennetegner denne erfaringsformen, selv om disse to filosofer har til dels ulike syn på hva det betydningsfulle består i.

Utgangspunktet for å anse den estetiske erfaring som betydningsfull, er synet på at det å ha en estetisk erfaring - også som tilskuer - er å anse som (prosess og) handling (Rancière 2006a; Dewey 2008). Det å bivåne noe, er ikke det samme som å være passiv. I møtet med kunst, bærer enhver publikummer på sin egen historie, en historie tilskueren allerede er aktør i. Når eleven forholder seg som tilskuer, og har en estetisk erfaring, betyr dette at eleven er aktivt på et indre plan; tilskueren er en meddikter (Rancière, 2009a; Dewey, 2008). Dewey benevner dette som en prosess av å gjøre og å gjennomgå, hvilket vil si at subjektet både er skapende i erfaringen, og selv blir formet av den. Dette gjelder både for den som tilvirker eller utøver kunst og den mottagende publikummer.

Rancière ser også estetiske erfaringer som det å gjøre og det å gjennomgå. Den estetiske erfaring er ikke en ren sanselig erfaring. Erfaringen er også følelsesmessig, og betinges av en tolkning som gir sanseerfaringen mening: "What kind of world is given to you, and how do you make sense of that given sensory world?" (Rancière, 2008a, s. 71). Den aktiviteten, eller den gjøren, som ligger i det å tolke, kan sammenlignes med det Dewey (2008) benevner som rekonstruksjon av tidligere erfaringer. Men Dewey og Rancière har ikke sammenfallende syn med hensyn til hva denne rekonstruksjonen, eller tolkningen, innebærer. Det er særlig i synet på hva som gjennomgås, at forskjellene mellom dem trer fram. Disse forskjeller vil jeg vende tilbake til. Men først, la meg si noe om "den estetiske erfaring som persepsjon", siden det hjelper oss til tydeligere å se forskjellene mellom Rancière og Dewey.

Fordi den estetiske erfaringen ikke bare handler om sansning, men også om følelse, er den refleksiv. Og dermed en aktivitet. Når eleven møter kunst som resepsjon - det vil si som mottagende publikummer - vil det være elevens persepsjon som er det aktive element i deres estetiske erfaringer. Persepsjon betyr både sansning og erkjennelse, og derfor er det slik snakk om en meningsbærende persepsjon i den estetiske erfaring (Rancière, 2006b; Dewey, 2008). Estetisk erfaring som persepsjon kan, slik jeg leser Rancière og Dewey, sies å romme alle de tre elementer som knyttes opp til "en estetisk dimensjon", samtidig som det reseptive, det skapende og det kritiske element ikke kan sees som utskillbare deler i denne persiperende erfaringsformen. 
Det å se en (teater)forestilling innebærer en følelsesmessig og mental aktivisering, under forutsetning av at den nedfeller seg som en estetisk erfaring. Dette vil jeg ytterligere belyse ved å se på henholdsvis Rancières og Deweys tenkning rundt estetisk erfaring som reseptiv persepsjon. Vi skal se at kritikk ligger innbakt/implisitt i denne erfaringsformen, og at den estetiske erfaringen man kan få som publikummer både er reflekterende og skapende - slik kunst som produksjon også må være det.

\section{Politisk frigjøring}

Kunst som persiperende og estetisk erfaring, er en spesiell erfaring som opphever de vanlige forbindelsene mellom skinn og virkelighet, form og materiale, aktivitet og passivitet, forstand og sansning. Rancière (2006) viser hvordan det skjer en sammensmelting av sansning og kognitiv aktivitet i den estetiske erfaring. Dette utgjør en spenningsfylt, men meningsbærende forening av natur og kultur. Dissensualitet er det begrep Rancière (2008b, 2009d) bruker for å beskrive relasjonen og samtidig det motsetningsfylte som ligger mellom en sanselig erfaring og den fortolkning som gir den sanselige erfaringen mening. Den relasjonelle overensstemmelsen mellom tankens aktivitet og den sanselige mottagelighet - som også kan sees som en forening av subjekt og objekt - tilhører i følge Rancière (2006a, 2009b) en menneskenatur som er tapt. I dette legger han at det i en dualismefri verden var en overensstemmelse mellom evnen til aktivitet og mottagelighet. "På denna överensstämmelsens förlorade plats träder den omedelbara föreningen, föreningen utan begrepp om motsatser, den rena avsiktliga aktiviteten och den rena passiviteten" (Rancière, 2006a, s. 87).

Dissensualitet angir ikke en motsetning mellom sansning og kognisjon. I den estetiske erfaringen er det ingen forskjell mellom logos (fornuft i tanke) og pathos (lidenskap i følelse). Det å erfare kunst handler om aktivitet både gjennom persepsjon og fortolkning, og slik utfordrer den estetiske erfaring motsetningen mellom å se og å handle. Publikums møte med figurteater er et godt eksempel på dette. Det å gi liv til teaterdukken avhenger ikke bare av dukkespilleren, men er helt avhengig av et publikum som projiserer sin fantasi og innbilningskraft inn i figurene. Publikum må forestille seg at figurene har liv. Jeg har spilt med dukker og figurer i forestillinger for barn og unge fra barnehage til og med videregående skole. Jeg har erfart at voksen ungdom, i likhet med barnehagebarn, har tatt kontakt etter forestillingen med ønske om å ta dukker og scenografi nærmere i øyesyn, etter åpenbart å ha latt seg berøre av det de har sett og opplevd. Opplevelsen av møtet med - de da akk så døde karakterene bak scenen etter forestilling, tilkjennegis av de besøkende som forunderlig. Helt konkret er det ofte dukkenes faktiske størrelse som kommenteres. Publikum tilkjennegir ofte å ha opplevd dem mye større, i tillegg til at dukkene tilsynelatende var pustende tilstede. Tilskueren har da aktivert sin innbilningskraft i møtet med den gitte forestillingen. Når man som publikum overværer for eksempel en teaterforestilling, vil både den sanselige følsomhet og den skapende aktivitet begge være virksomme. Tilskueren deltar ved å omforme forestillingen på sin egen måte, og slik er man på samme tid en distansert publikummer og en aktiv fortolker.

Ifølge Rancière (2009b) representerer den estetiske erfaring en ekstraordinær erfaringssfære som skaper et brudd med vanlige sanseerfaringer, og ved det et brudd med de maktrelasjoner som vanligvis strukturerer våre hverdagserfaringer. Dette fordi strukturen i relasjonene mellom å snakke, se og høre tilhører dominansens og underkastelsens struktur. Rancière mener frigjøring, eller emansipasjon, starter når vi innser at det å se - eller med andre ord; bivåne og persipere noe - også er en handling som stadfester eller forandrer distribusjonen av posisjoner (Rancière, 2009a).

Ved at den estetiske erfaring unndrar seg regler og kontroll, vitner denne erfaringen om at samfunnets fordeling av identiteter og posisjoner er relativ. Den estetiske erfaring representerer slik et 
brudd med den ordinære måten å erfare på, og gjennom forandret persepsjon kan man skape seg "en ny kropp og en ny levd verden", skriver Rancière (2008a, s. 71). Dette er hva han kaller politisk subjektivering. Eller med andre ord, en avidentifiserings- eller avklassifiseringsprosess. Rancière (2006a) beskriver den politiske subjektivering som iverksettelse av en rettferdighet, eller håndtering av en urett. Den estetiske erfaring representerer i seg selv en slik subjektivering ved at den rokker ved hierarkiske grenser. I vår sammenheng kan vi se for oss elevens mulighet til - gjennom estetisk erfaring - å kaste av seg sin rolle tildelt gjennom (skole-)virkelighetens ulike rangeringer. I følge Rancière (2009a) skaper denne erfaringssfæren et menneskelig fellesskap som åpner for nye måter å definere og forvalte det som er felles. Det sanselige, eller dissensuelle fellesskapet er et likebyrdig fellesskap, og kunsten kan "skape, eller gjenskape båndene mellom enkeltindividene og fremkalle nye former for konfrontasjon og deltagelse" (Rancière, 2008b, s. 535). Den enkeltes politiske subjektiveringsprosess påvirkes slik direkte av kunst som estetisk erfaring. "Det handlar här altså inte bara om konstnärliga frågor, utan om de sätt på vilka vår värd i dag låter sig förnimmas och på vilka makterna bekräfter sin legitimitet" (Rancière, 2006a, s. 90).

Hva betyr så dette i praksis? Er ikke følelsen av frigjøring i den estetiske erfaring en illusorisk frigjøring? I følge Rancière (2006b) er ikke dette mer illusorisk enn myten om en determinert og selvsagt inndeling av mennesketyper. Rancière (2006a) vektlegger (an)erkjennelsen av vår alles likhet i den estetiske erfaringen. Ikke bare som likeverdighet, men som reell likhet i vår evne til estetisk persepsjon og til fornuftig tenkning. I den estetiske erfaring ligger mulighet for en omfortolkning av den sosiale virkeligheten, og slik er estetikken selve det området som muliggjør politikkens fornyelse (Rancière, 2008b).

Her kan det igjen være fruktbart å se på hva som skjer når en tilskuer blir presentert for figurteater. $\AA$ la seg rive med av historien fortalt - og de levende bilder gitt - gjennom animasjon eller "levendegjøring" av døde objekter, fordrer evnen vi alle har til å forestille oss noe i fantasien. Den innbilningskraften som må til fra tilskuerens side for å oppleve teaterdukken som levende og besittende en vilje, svarer til den forestillingsevnen som enhver estetisk erfaring gir. Den estetiske erfarings erkjennelsesmåte er, i følge Rancière (2006b), spunnet ut av nettopp opplevelsen: "som om". Med andre ord en forestillingsevne - eller kontrafaktisk tenkning (tenk hvis...) - som igjen kan virke forandrende på selvopplevelsen og synet på den sosiale virkeligheten.

Rancière ser ikke politikk som en kamp om makt, men som en prosess av deling av det sanselige. Ulike distribusjoner av det sanselige påvirker vår måte å oppfatte og snakke om virkeligheten på, og derved legger den føringer for politisk tenkning og handling. Rancière (2006b) knytter den individuelle kunsterfaringen til politisk frigjøring. Ikke gjennom kunstens budskap og de følelser den formidler $\mathrm{i}$ forhold til verdens beskaffenhet, men gjennom en ny inndeling av det materielle og symbolske rommet, og hvordan den avgrenser denne tiden og fyller dette rommet (Rancière, 2008b). "Kunstens praksiser og forskjellige former for synlighet deltar selv i delingen og rekonfigureringen av det sansbare", skriver Rancière (2008b, s. 537), og "disse formene inndeler rom og tid, subjekter og objekter, det som er felles og det som er singulært”.

Estetisk erfaring er uten destinasjon, den er "a finality without end" (Rancière, 2006b, s. 5). Estetisk erfaring er med andre ord ikke middel for noe annet, men nok i seg selv. Ved at den sanselige mottagelighet og tankens aktivitet blir til en og samme virkelighet i den estetiske erfaringen, opplever vi slik sanselig erkjennelse av timelighet og evighet, og av virkelighet og utopi (Rancière, 2006a). Rancière (2009b) omtaler den spenningen, eller dissensualiteten, som alltid finnes mellom sansning og fortolkning, for "skjønnhet". Det dissensuelle, eller skjønne, er ikke en egenskap ved verket, eller 
objektet, men befinner seg i selve erfaringen - i det som oppstår i møtet mellom gjenstand og betrakter.

I følge Rancière (2009b, s. 103) er skjønnhet i den estetiske erfaring uvergelig knyttet til dissonans og ubestemmelighet/uavsluttethet (indefinitely). I møtet med kunst omfatter dissensualitet også spenningsrommet mellom form og materie, kunst som tiltrekkende og frastøtende og forholdet mellom passivitet og aktivitet. Denne spenningen preger med andre ord den estetiske erfaringen på flere plan, og er det som gir denne ekstraordinære erfaringsformen et frigjørende potensial (Rancière, 2009c, s. 32). Rancière sier at det er gjennom en uopphørlig stadfesting av denne splittelsen som et gode, at frigjøring overhodet er mulig. Skjønnhet er med andre ord ikke det samme som det behagelige, og den estetiske scene er i følge Rancière (2009b) det uforsonliges scene.

Når barn og unge møter forestillinger i DKS som publikum, vil de omforme forestillingen på sin egen måte. De vil være meddiktere. Alle kunstuttrykk kan komme til å omgjøre rammen for persepsjoner, og forandre dynamikken i våre følelsesreaksjoner (Rancière, 2009a). I og med at den estetiske erfaring representerer et brudd med den ordinære måten å erfare sanselig, innebærer denne tolkningen en forandrende aktivitet som kan virke frigjørende: Gjennom forandret persepsjon skaper man for seg selv " en ny kropp og en ny levd verden" (Rancière, 2008a, s. 71). Det handler om hva som kan bli sett og hva som kan bli sanset: "That is what was at stake in emancipation: getting out of the ordinary ways of sensory experience", sier Rancière i et intervju (2008a, s. 71). Ved at kunsten knytter sammen det individuelle kunstverk med vårt alles liv, kan kunsten i følge Rancière (2006a), bøte på en menneskelig eksistensiell ensomhet. Når elevene er publikum i møtet med kunst, gis de en mulighet for det Rancière kaller "politisk subjektivering". Den politiske subjektivering er noe som skjer i selve den estetiske erfaringen. På dette grunnlag kan vi hevde at denne erfaringsformen er dannende i seg selv. Men det utelukker ikke at den estetiske erfaringen kan influere på (politisk) handling.

\section{Rekonstruksjon}

Vi har sett at Rancière vektlegger den estetiske erfarings relasjonelle overensstemmelse mellom tankens aktivitet og den sanselige mottagelighet. Denne overensstemmelsen ser han (2006a, 2009b) som tilhørende en menneskenatur som er tapt. Dette harmonerer med det evolusjonistiske perspektivet hos John Dewey (2008).

Deweys beveggrunn for å se estetisk mottagelighet som aktivitet, er ikke koblet til frigjøring, som i Rancières tenkning. Dewey (2008) vektlegger i større grad den betydning erfaringen har for menneskets liv (og læring) generelt. Dette henger sammen med Deweys syn på alt liv - samt menneskets bevissthet - som et resultat av evolusjonen, og derfor et resultat av samhandling med omverdenen. Liv er betinget av bevegelse, og Dewey mener at mennesket har en biologisk disposisjon til å gjenopprette balanse der den ikke finnes. Alt som hindrer bevegelse skaper behov og trang behov som i følge Dewey kan tilfredsstilles gjennom estetiske emosjoner i en estetisk erfaring. De estetiske emosjoner framkalt i møtet med kunst, er tilfredsstillende fordi de ledsager det opplevde, eller persiperte, i en bevegelse mot en harmonisk enhet. I den estetiske erfaring skapes det en fusjon, eller en syntese mellom kunstobjektets kvaliteter og de følelser som objektet vekker. Dette er et harmonisk høydepunkt i den estetiske erfaringen som kan beskrives som sammensmelting mellom subjekt og objekt. Eller som han også skriver: "som en fullstendig integrasjon mellom organismen og dets omgivelser" (Dewey, 2008, s. 281). Det harmoniske høydepunkt i den estetiske erfaring 
kulminerer i fornyet deltagelse og kommunikasjon, og slik er det - i følge Dewey - en framdrift i all erfaring, også i den estetiske.

I likhet med Rancière, ser Dewey (2008) mottagelighet og assimilasjon som vital aktivitet på linje med direkte og synlige handlinger, og anser ikke det å oppleve, det å skape og det å vurdere som adskilte operasjoner i den estetiske erfaring. I den estetiske erfaring binder det emosjonelle erfaringen sammen til en helhet, det intellektuelle gir erfaringen mening og det praktiske viser til at erfaringen finner sted i interaksjonen mellom mennesker og miljø (Dewey, 2008). Også fantasirikdom vil, i følge Dewey, være en kraft som forener de materielle bestanddelene i et kunstverk, og ved det skaper et hele av dem, tross deres forskjellighet. Slik er interaksjonen med kunstens materiale en individuell måte å se og føle på, og kunst som erfaring autonom. Dette betyr at det ikke er en direkte vei fra intensjonene bak for eksempel en scenisk oppsetning, og hvordan forestillingen faktisk kommuniserer, - noe Rancière (2009a) også peker på. Det at elevene, det være seg små barn eller voksen ungdom, får anledning til å se ulike kunstuttrykk som publikum, gir den enkelte mulighet til å være tolkende og medskapende. Derfor er det et spørsmål om ikke vi - i vår tolkning av elevene som publikum - skal vokte oss, slik at vi ikke kommer i skade for å avvise deres oppmerksomhet som passivitet.

Det å oppleve kunst og erfare estetisk, beskrives av Dewey (2008) som en stimulerende og livgivende erfaring: "But whatever path the work of art pursues, it, just because it is a full and intense experience, keeps alive the power to experience the common world in its fullness" (s. 138). Han understreker den estetiske erfaringens umiddelbarhet: "It cannot be asserted too strongly that what is not immediate is not esthetic" (Dewey, 2008, s. 123). Men selv om den estetiske erfaringen har dette øyeblikkelige ved seg, så kommer ikke den umiddelbare opplevelsen som lyn fra klar himmel. I følge Dewey (2008) ligger dens kilde i tidligere estetiske erfaringer, hvor vi også har opplevd umiddelbar sansing og følelse av det estetiske.

Dewey (2008) ser den estetiske erfaringens aktive og inntrengende persepsjon som en refleksiv og rekonstruerende prosess. Det vil alltid være en avstand, eller et gap mellom den nåværende interaksjon og den forståelsen vi har av den. Den sansede, eller persiperte, relasjonen mellom det mennesket "gjør og gjennomgår" er bevisst erfaring. Den erfaringen vi gjør, tolkes og forstås gjennom tidligere erfaringer. Og denne fusjonen av nytt og gammelt er, i følge Dewey (2008), det samme som menneskets fantasi og innbilningskraft. I divergensen mellom tidligere erfaringer nedfelt i minnet og den nye opplevelsen - som Dewey ser som fantasi - kan det oppstå noe nytt, noe tidligere ukjent. Dette harmonerer med synet på danning som en prosess som strekker seg mot den ideelle fordring og utopi. I Rancières visjon om et dissensuelt og likebyrdig fellesskap, er imidlertid det utopiske aspektet mer åpenbart enn hos Dewey.

I følge Dewey (2008), bibringer den estetiske erfaring kunnskap gjennom persepsjon, innbilningskraft og intuisjon. I kunst som estetisk erfaring, mener Dewey vi har å gjøre med det han kaller transformert kunnskap, i og med at kunnskapen blir iblandet ikke-intellektuelle elementer. Denne transformere kunnskapen innebærer noe mer enn kunnskap. Slik jeg leser Dewey, er dette "noe mer" knyttet opp til en ekstraordinær tilstedeværelse i denne erfaringsformen. Derfor kan ikke den estetiske erfarings dype følelse av meningsfylde forveksles med flyktig behag.

\section{Estetisk erfaring - en danningsprosess?}

Dewey (2008) ser en nødvendig spenning og motstand i den betydningsdannelse rekonstruksjonen av tidligere erfaringer skaper, og Rancière (2008b, 2009b, 2009d) ser foreningen av sansing og tolkende aktivitet i den estetiske erfaring som spenningsfull. Jeg tolker overvinnelsen av den motstand som 
ligger i den estetiske erfaringens rekonstruksjon (Dewey, 2008) - og det Rancière (2009d) benevner som motsetningsfull dissensualitet - som dannende element i den estetiske erfaring.

De estetiske erfaringene aktiviserer inderlige sinnsbevegelser, og det er ved å vekke disse affektene at kunsten er politisk, i følge Rancière (2009d). Nettopp i det spenningsfulle ligger et frigjørende potensial som kan komme til å fremkalle nye former for konfrontasjon og deltagelse (Rancière, 2008b, 2009a). Gjennom en forandret persepsjon som virker omformende på våre følelsesreaksjoner og fornemmelser, skjer den individuelle politiske danning i erfaringen selv, samtidig som den estetiske erfaring også vil kunne påvirke sosial og politisk handling i ettertid.

Dewey (2008) tilkjennegir at den estetiske erfaringen gir en umiddelbar og intuitiv opplevelse av mening og sammenheng, samtidig som erfaringens rekonstruerende prosess beskrives som avgjørende for de betydninger som skapes. Det vil alltid ligge en motstand i rekonstruksjonenen av tidligere erfaringer, og når denne motstanden overvinnes og vi slik gjenfinner balanse, har prosessen framdrift. Dette vekst- og utviklingsperspektivet utelukker ikke at kunst som erfaring virker dannende, eller omformende, på mennesket. Den prosess som oppstår i det individuelle møtet med kunsten kan beskrives som en dialektikk og en symbiose mellom kunstens materiale og mokttagerens medskaping.

Det Rancière (2006a, 2008a) omtaler som "subjektiveringsprosessen" i den estetiske erfaringen, kan også sies å være en prosess som handler om fantasi og rekonstruksjon. Mellom det som sanses og fortolkningen av sansningen, ligger det en spenning som yter den erfarende motstand. Rancière anser denne tolkningsprosessen i den estetiske erfaring, som meningsstiftende og verdifull i seg selv, samtidig som prosessens "spenningsrom" åpner for hva Rancière kaller "utopisk tenkning", noe han anser nødvendig for den enkeltes frigjøring, - og for den enkeltes danning til et dissensuelt og likebyrdig fellesskap.

Estetiske erfaringer er, som vi har sett, viktige i menneskets danningsprosess. Men kan man si at opplevelse av betydningsdannelse i den estetiske erfaring også gir innsikt? Den første teori om estetisk erfaring lanserte Alexander Gottlieb Baumgarten da han på midten av 1700-tallet grunnlegger den filosofiske estetikk som teorien om sanselig, (eller sensitiv) erkjennelse (Baumgarten, 2008). Baumgarten skiller mellom logisk og estetisk bevissthet, og hevder at det finnes en egen form for estetisk rasjonalitet og erkjennelse. Denne sanselige erkjennelse er estetisk erfaring, og den estetiske erfaring gir mulighet for å erkjenne verden på en ulik måte enn den logiske erkjennelse (Baumgarten, 2008). Den estetiske erfaring kan slik sies å gi adgang til en dimensjon av tilværelsen, som logikken ikke har tilgang til.

Nettopp fordi betydningsdannelse gjennom den estetiske erfaring ikke bare er knyttet til det sanselige, men også til det sensitive og følsomme, representerer dette en selvstendig form for erkjennelse (Baumgarten, 2008). Rancière og Dewey kan enes om den estetiske erfarings opplevelse av meningsfylde, selv om de har ulikt syn i forhold til hva det vesentligste med denne opplevelsen av mening er - og hvordan mennesket dannes gjennom denne erfaringsformen.

Danning er ikke noe som er forbeholdt de få, men er en prosess tilgjengelig for alle. Dette er en forandrende prosess uten sluttpunkt - en humaniserende prosess, vil mange mene: Danning er i utgangspunktet selvdanning, men filosofisk danningstenkning vektlegger også individets forhold til verden og samfunnet, og ikke bare individets forhold til seg selv (Korsgaard \& Løvlie, 2003). Det betyr at danning vanskelig kan skilles fra det politiske og det etiske.

Danning er sosialt betinget for Dewey, og for ham representerer det demokratiske systemet hva politisk danning skal ruste den enkelte til å forvalte. Dette i motsetning til Rancière, som er av den 
oppfatning at ingen politikk qua system - heller ikke det demokratiske - kan frigjøre, eller skape emansipasjon for den enkelte. For ham er derfor det bestående som system noe politisk danning kan ruste den enkelte til å stå opp i mot. Der det i et hierarkisk samfunn vil være snakk om distribusjon av det sanselige til de få, er det i Rancières tenkning snakk om en re-distribusjon av det sanselige til alle. Slik representerer Rancière og Dewey ulike syn på hva det vil si å dannes i og til polis. (Nå levde Dewey $\mathrm{i}$ en annen tid - men hans tenkning står i kontrast til Rancière, og hans mer - $\mathrm{i}$ beste betydning - anarkistiske syn.)

Danning leser jeg hos Rancière, som den frigjøring som ligger i enhver gjenoppretting av rettferdighet - noe subjektiveringen i den estetiske erfaring gjør i pakt av å "omfortolke" den sosiale virkeligheten. I Rancières (2006a) tenkning er subjektiveringsprosessen meningsstiftende. Jeg forstår Rancière slik at han anser at estetisk erfaring allerede rommer et element av innsikt, ved at denne erfaringen representerer en fortolket versjon av en opplevelse eller sanselig erfaring, og at denne innsikt ikke kan bli tilveiebrakt av logisk "sann" viten.

Fellesskap, slik Dewey $(2008,2005)$ presiserer, handler i stor grad om kommunikasjon. Men det menneskelige fellesskap av dissensualitet kan, slik jeg leser Rancière (2009b), virke politisk frigjørende uten (nødvendigvis) å kommuniseres. Ved å se politikk som en prosess av ulike måter å inndele den sansbare verden på, argumenterer Rancière for at det åpnes muligheter for nye fellesskap. Fellesskap gjennom (autonome) estetiske erfaringer.

Kan skole-Norges skepsis til publikumsrollen elevene blir tilbudt i Den kulturelle skolesekken (Vibe et al., 2009), bunne i et syn på kontemplasjon som åndsfraværende passivitet - eller også en ambivalens til dette begrepet? $\AA$ anse kunstformidling i forestilling-, utstilling- eller konsertform som monologisk fordi elevene ikke er medvirkende i fysisk eller verbal forstand (Borgen \& Brandt, 2006), kan tyde på dette. For å undersøke om kunsterfaringen som estetisk erfaring virker dannende på eleven, må man - som Rancière og Dewey - forstå aktivitet $i$ et videre perspektiv. De peker begge på den intense følelse av aktiv tilstedeværelse i den estetiske erfaring som persiperende tilskuer.

Dewey (2008: 259) skiller mellom attention og contemplation. Estetisk kontemplasjon i passiv betydning, løsrevet fra menneskets psyke og kropp, og derved livets øvrige erfaringer, ser Dewey som altfor snevert i forhold til hva estetisk erfaring omfatter. Allikevel må vi, for å bli påvirket, hengi oss i aktiv fordypelse, sier Dewey. Dette handler ikke om kontemplasjon i passiv forstand, men om responsiv aktivitet. Persepsjon handler ikke om inaktiv og avsondret kontemplasjon, men realiserer både sansning, følelse og tenkning. Selv om konsentrert oppmerksomhet er et vesentlig element i all genuin persepsjon, er denne faktoren ikke den eneste som kjennetegner en estetisk erfaring. I følge Dewey (2008) kan fysisk virksomhet og sinnsbevegende følelser, så som begjær eller begeistret betatthet, ikke utelukkes fra den estetiske erfaringen.

Rancière (2006a) forstår kontemplasjon som aktivitet. Han sier at den sanselige følsomhet og mottagelighet i den estetiske erfaring forenes med, eller blir ett med, tankens skapende aktivitet. Han bruker også uttrykket "sanselig passivitet" i forening med "aktiv intelligens" (Rancière, 2006a, s. 88).

Kontemplasjon i betydningen aktiv indre tilstedeværelse, eller det Dewey (2008) vil kalle oppmerksomhet (attention), er et viktig aspekt ved estetiske erfaringer. Uansett valg av begrep, handler denne erfaringsformen om stor indre vitalitet. Rancière og Dewey tydeliggjør begge hvordan den reseptive siden i den estetiske dimensjon - hvis det er snakk om en estetisk erfaring - ikke er å anse som åndsfraværende passivitet. Estetiske erfaring som resepsjon er reflekterende, kritisk og skapende - slik kunst som produksjon også må være det. 
Kunst som erfaring - også i betydningen av kunstresepsjon - kan virke transformerende på mennesket og dets omgivelser fordi den estetiske erfaringen rommer kritisk refleksjon og skaping. (Dewey, 2008; Rancière, 2006a, 2008a). Dette indikerer en sammenheng mellom kunst og danning. Ingen andre erfaringsformer kan erstatte den estetiske. Derfor kan kunstopplevelse gi en form for innsikt som "skolske" erfaringer - hvilket vil si metodiske og vitenskapelige erfaringer - ikke på noen måte gir tilgang til.

\section{Refleksjon rundt kunstmøter i Den kulturelle skolesekken}

Når elevene møter profesjonelle kunst- og kulturtilbud med høy kunstnerisk kvalitet gjennom DKS, er det nødvendigvis ikke gitt at alle har en ekstraordinær opplevelse og slik får en estetisk erfaring. Dette kan det være ulike årsaker til, men å trekke den konklusjon at elevene må aktiviseres i praktiske prosesser for at kunstopplevelser skal kunne kommunisere, harmonerer dårlig med hva den estetiske erfaring som resepsjon kan sies å romme på bakgrunn av Dewey og Rancieres tekster. Når Dewey og Rancière begge ser kunst som erfaring, anser de også mottagerens estetiske erfaring som skaping. Den estetiske erfaring innebærer en indre aktivitet, som ikke bare handler om sansning, men også om følelse og refleksivitet. Slik betinger estetisk erfaring både fysisk og mental tilstedeværelse. Det er ikke nødvendigvis sånn at presumptivt god kunst nødvendigvis gir alle en estetisk erfaring, uansett om elevene er aktivt seende og lyttende til stede. Kunst er kommunikasjon, men kunsterfaringen handler også om en interaksjon som må finne sted. Oppstår ikke den i elevens møte med kunsten, behøver konklusjonen verken å være at eleven var åndsfraværende, eller manglende kvalitet i kunstuttrykket. Kunst kan aldri helt defineres. Og smaksdommer har ingen fasit.

Deltagelse og kommunikasjon er, i lys av Deweys og Rancières tekster, noe som spinner ut av estetisk erfaring. Dewey grunner dette i et biologisk perspektiv, mens Rancière ser det fra et politisk perspektiv. Dette kan sees som en instrumentell funksjon kunst som erfaring har. Men kanskje er det ingen motsetning mellom å se kunst som en erfaringsform som kun tjener sin egen hensikt - som en helhetlig erfaring uten instrumentell bestemmelse - og samtidig tilkjennegi denne erfaringsformen en faktisk og tenkelig virkningshistorie. Danning kan sies å skje i erfaringen selv, ved at en forandret persepsjon virker omformende på følelser og innsikt, samtidig som den estetiske erfaring også vil kunne påvirke senere sosial og politisk handling. Den estetiske erfaring kan slik karakteriseres som uten mål, men med mening. Den estetiske erfaringen er, ved ikke å handle om "nytte", en motvekt til den instrumentelle fornuft. En eksistensiell nødvendighet for mennesket, i følge Rancière, og et nødvendig vekst- og utviklingsgrunnlag for mennesket, i følge Dewey.

De to forskjellige filosofier jeg har fordypet meg i, representerer ulike perspektiver som jeg mener til sammen bibringer forståelse for hva den estetiske erfaring kan romme. En fellesnevner for tekstene er at den estetiske erfaringen anses som ekstraordinær og vesentlig. Til tross for at de vektlegger forskjellige aspekter, mener både Rancière og Dewey at som mottagelse og persepsjon, rommer den estetiske erfaring skaping og refleksiv kritikk, og begge anser - hver på sin måte - at denne erfaringsformen har stor betydning for mennesket.

Hva den enkelte elev sitter igjen med etter erfaring av og med kunstuttrykk, kan ikke måles og veies. Slik estetiske erfaringer ikke er gitt i praktiske prosesser i samarbeid med kunstnere, er de heller ikke gitt i møtet eleven som publikummer har med kunst. Dette gjelder selv om eleven er en oppmerksom tilskuer og det er kvalitet i kunstuttrykket. Den viktige erkjennelse Dewey og Rancière tenkning synliggjør - tross betydelige forskjeller - er at hvis kunsterfaringen er estetisk, så er erfaringen vesentlig og betydningsfull. Og slike erfaringer danner mennesket. 


\section{Presentasjon av forfatteren}

Helene Kristin Oftedal har master i pedagogikk, bachelor i kultur og samfunnsfag og praktiskpedagogisk utdanning innen teater. Hun har 3-årig kunstutdanning innenfor figurteater, og har i mange år jobbet profesjonelt som dukkespiller/skuespiller.

\section{English abstract}

\section{«The cultural rucksack»: passive presence or active formation?}

Based on the experiences from "Den kulturelle skolesekken" (The cultural rucksack) - a national effort which ensures that every pupil in Norway gets the opportunity to experience professional art and culture of various kinds - this article takes a closer look at art as aesthetic experience. Based on texts by the philosophers Jacques Rancière and John Dewey, the article examines the educational potential of aesthetic experience as reception. From a political and, respectively, an evolutionary perspective, both Rancière and Dewey emphasize the aesthetic experience as an inner activity which is both creative and critical. The art experience is characterized not only as harmonious moments, but also as a process involving a certain tension due to the reconstruction and interpretation of what is sensed and experienced. In this way the role of the audience at school performances is understood as active formation more than passive presence.

\section{Referanser}

Baumgarten, Alexander Gottlieb (2008). Fra Aesthetica (1750). I Kjersti Bale \& Arnfinn Bø Rygg (red.). Estetisk teori, En antologi (s. 11-17). Oslo: Universitetsforlaget.

Borgen, Jorunn Spord og Brandt, Synnøve S. (2006). Ekstraordincert eller selvfølgelig? Evaluering av Den kulturelle skolesekken i grunnskolen, Rapport 5. Norsk institutt for studier og forskning (NIFU STEP), Senter for innovasjonsforskning: Oslo

Cannatella, Howard. (2008). The Richness of Art Education. Rotterdam/Taipei: Sense Publishers

Carroll, Noël. (2001). Beyond Aesthetics. Philosophical Essays Cambridge: Cambridge University Press. http://dx.doi.org/10.1017/CBO9780511605970

Dewey, John. (2005). Demokrati og uddannelse. Århus: Forlaget Klim.

Dewey, John (2008). Art as experience. The Later Works, 1925-1953 Volume 10: 1934.Illinois. U.S.A.: Southern Illinous University.

Elliot, David J. (1995). Music matters. Oxford: Oxford University Press

Korsgaard, Ove \& Løvlie, Lars (2003). Indledning. I Rune Slagstad, Ove Korsgaard \& Lars Løvlie (red.) Dannelsens Forvandlinger (s. 9- 39). Oslo: PAX Forlag A/S.

Kunnskapsdepartementet.(2006). Loereplaner for kunnskapsløftet, Generelle del. Oslo, Departementet. Nedlastet 4. juli 2011 fra http://www.udir.no/upload/larerplaner/generell del/generell del lareplanen bmf.pdf

Kunnskapsdepartementet. (2007). Skapende loering, Strategiplan for kunst og kultur i opplaeringen. Oslo: Departementet. Nedlastet 4. juli 2011 fra http://www.regjeringen.no/upload/KD/Vedlegg/Grunnskole/Strategiplaner/Strategi_kunstogkultur. pdf

Rancière, Jacques (2006a). Texter om politik och estetik. Nörhaven: Sveriges Bildkonstnärsfond.

Rancière, Jacques (2006b). Thinking between disciplines: an aesthetics of knowledge.

PARRHESIA Journal, 2006 (1), s.1-12. Nedlastet 1. juli 2011 fra http://www.parrhesiajournal.org./parrhesia01/parrhesia01_ranciere.pdf 
Rancière, Jacques (2008a). Art is going elsewhere. And politics has to catch it. Sudeep Dasgupta interviews Jaques Rancière. Krisis, Contemporary Journal for Contemporary Philosophy 2008 (1), s.70-76 Nedlastet 1. Juli 2011 fra http://dare.uva.nl/document/138101

Rancière, Jacques (2008b). Estetikken som politikk. I Bale, K. \& Bø-Rygg, A. (Red.), Estetisk teori, En antologi (s. 533- 550). Oslo: Universitetsforlaget.

Rancière, Jacques (2009a). The emancipated spectator. London, New York: Verso.

Rancière, Jacques (2009b). Aesthetics and its discontents. Cambridge, UK and Malden, USA: Polity Press.

Rancière, Jacques (2009c). The Aesthetic Unconsciounes. Cambridge, UK \& Malden, USA: Polity Press.

Rancière, Jacques (2009d). The Method of Equality. I Rockhill,G.\& Watts, P. (Eds.) Jacques Rancière, History, Politics, Aesthetics (s. 273-288). Durham and London: Duke University Press.

Steinsholt, Kjetil og Dobson, Stephen. (Red.) (2011). Dannelse, Introduksjon til et ullent pedagogisk landskap. Trondheim: Tapir Akademiske Forlag.

Stortingsmelding nr. 38 (2002 - 2003). Den kulturelle skolesekken. Nedlastet 3. juli 2011 fra http://www.regjeringen.no/nb/dep/kud/dok/regpub1/stmeld/20022003/stmeld-nr-38-2002-2003.html?id=197053

Thavenius, Jan (1995). Den motsägelsesfulla bildningen. Stockholm/Stehag: Brutus Östlings Bokförlag Symposion.

Vibe, Nils, Evensen, Miriam og Hovdhagen, Elisabeth (2009). Spørsmål til Skole-Norge.Tabellrapport fra Utdanningsdirektoratets spørreundersøkelse blant skoler og skoleeiere våren 2009, Rapport 33. Norsk institutt for studier og forskning (NIFU STEP), Senter for innovasjonsforskning: Oslo. 